University of Nebraska - Lincoln

DigitalCommons@University of Nebraska - Lincoln

\title{
Long-term dynamics of uranium reduction/reoxidation under low sulfate conditions
}

John Komlos

Princeton University

Aaron Peacock

Microbial Insights Inc.

Ravi K. Kukkadapu

Pacific Northwest National Laboratory, ravi.kukkadapu@pnl.gov

Peter R. Jaffe

Princeton University, jaffe@princeton.edu

Follow this and additional works at: https://digitalcommons.unl.edu/usdoepub

Part of the Bioresource and Agricultural Engineering Commons

Komlos, John; Peacock, Aaron; Kukkadapu, Ravi K.; and Jaffe, Peter R., "Long-term dynamics of uranium reduction/reoxidation under low sulfate conditions" (2008). US Department of Energy Publications. 162. https://digitalcommons.unl.edu/usdoepub/162

This Article is brought to you for free and open access by the U.S. Department of Energy at DigitalCommons@University of Nebraska - Lincoln. It has been accepted for inclusion in US Department of Energy Publications by an authorized administrator of DigitalCommons@University of Nebraska - Lincoln. 


\title{
Long-term dynamics of uranium reduction/reoxidation under low sulfate conditions
}

\author{
John Komlos $^{\text {a }}$, Aaron Peacock ${ }^{\mathrm{b}}$, Ravi K. Kukkadapu ${ }^{\mathrm{c}}$, Peter R. Jaffé ${ }^{\mathrm{a}, *}$ \\ ${ }^{a}$ Department of Civil and Environmental Engineering, Princeton University, Princeton, NJ 08544, USA \\ ${ }^{\mathrm{b}}$ Microbial Insights Inc., Rockford, TN 37853, USA \\ ${ }^{\mathrm{c}}$ Environmental Molecular Sciences Laboratory, Pacific Northwest National Laboratory, Richland, WA 99352, USA
}

Received 30 October 2007; accepted in revised form 5 May 2008; available online 29 May 2008

\begin{abstract}
The biological reduction and precipitation of uranium in groundwater has the potential to prevent uranium migration from contaminated sites. Although previous research has shown that uranium bioremediation is maximized during iron reduction, little is known on how long-term iron/uranium reducing conditions can be maintained. Questions also remain about the stability of uranium and other reduced species after a long-term biostimulation scheme is discontinued and oxidants (i.e., oxygen) re-enter the bioreduced zone. To gain further insights into these processes, four columns, packed with sediment containing iron as Fe-oxides (mainly Al-goethite) and silicate Fe (Fe-containing clays), were operated in the laboratory under field-relevant flow conditions to measure the long-term ( $>200$ day) removal efficiency of uranium from a simulated groundwater during biostimulation with an electron donor ( $3 \mathrm{mM}$ acetate) under low sulfate conditions. The biostimulation experiments were then followed by reoxidation of the reduced sediments with oxygen.

During biostimulation, Fe(III) reduction occurred simultaneously with U(VI) reduction. Both Fe-oxides and silicate $\mathrm{Fe}(\mathrm{III})$ were partly reduced, and silicate Fe(III) reduction was detected only during the first half of the biostimulation phase while Fe-oxide reduction occurred throughout the whole biostimulation period. Mössbauer measurements indicated that the biogenic $\mathrm{Fe}(\mathrm{II})$ precipitate resulting from Fe-oxide reduction was neither siderite nor $\mathrm{FeS}_{0.09}$ (mackinawite). U(VI) reduction efficiency increased throughout the bioreduction period, while the Fe(III) reduction gradually decreased with time. Effluent $\mathrm{Fe}(\mathrm{II})$ concentrations decreased linearly by only 30\% over the final 100 days of biostimulation, indicating that bioreducible $\mathrm{Fe}(\mathrm{III})$ in the sediment was not exhausted at the termination of the experiment. Even though Fe(III) reduction did not change substantially with time, microorganisms not typically associated with $\mathrm{Fe}(\mathrm{III})$ and U(VI) reduction (including methanogens) became a significant fraction of the total microbial population during long-term biostimulation, meaning that most acetate was utilized for biological processes other than Fe(III) and U(VI) reduction. This corresponds with an electron donor/acceptor mass balance showing that the amount of $\mathrm{Fe}(\mathrm{III}), \mathrm{U}(\mathrm{VI})$ and $\mathrm{SO}_{4}{ }^{2-}$ reduced accounted for very little $(<2 \%)$ of the acetate consumed after day 104 of bioreduction.

Selected columns were reoxidized after 209 days by discontinuing acetate addition and purging the influent media with a gas containing $20 \%$ oxygen. Uranium reoxidation occurred rapidly with a very large uranium spike exiting the column (7-8 times higher than the original influent concentration) which resulted in $61 \%$ of the precipitated uranium resolubilized and transported out of the column after 21 days and virtually all of the uranium being removed by day 122 . During the first 21 days of reoxidation, the $\mathrm{Fe}(\mathrm{III})$ and $\mathrm{U}(\mathrm{VI})$ reducing microbial population, as measured by quantitative PCR, remained at pre-oxidation levels (even though the gene transcripts that represent the methanogen population decreased by $99 \%$ ) indicating that short-term disruptions in biostimulation (equipment failure, etc.) may not negatively affect the uranium reducing microbial population.
\end{abstract}

(C) 2008 Elsevier Ltd. All rights reserved.

\footnotetext{
* Corresponding author. Fax: +1 6092582799.

E-mail address: jaffe@princeton.edu (P.R. Jaffé).
}

This article is a U.S. government work, and is not subject to copyright in the United States. 


\section{INTRODUCTION}

Uranium contamination of groundwater is a concern at former uranium extraction and processing sites. The oxidized form of uranium, U(VI), tends to be soluble in groundwater and is transported readily as various uranyl ions (usually complexed with carbonate in natural systems) while the reduced form of uranium, U(IV), forms insoluble precipitates (e.g., uraninite) (Langmuir, 1978; Fredrickson et al., 2000; Senko et al., 2002). The bioreduction and subsequent precipitation of uranium from groundwater through the addition of an electron donor to stimulate the uranium reducing microbial population has shown potential to prevent uranium migration from contaminated sites (Lovley and Phillips, 1992a; Lovley and Coates, 1997; Abdelouas et al., 1998).

Biological (i.e., enzymatic) U(VI) reduction to U(IV) can occur simultaneously with $\mathrm{Fe}$ (III) reduction (Finneran et al., 2002; Anderson et al., 2003; Istok et al., 2004) and sulfate reduction (Lovley and Phillips, 1992b), although $\mathrm{U}(\mathrm{VI})$ reduction has been shown to decrease when the system changes from iron reducing to sulfate reducing conditions (Finneran et al., 2002; Anderson et al., 2003). Therefore, it is attractive to design a U(VI) bioreduction scenario under predominantly Fe(III) reducing conditions. Field-relevant (flowing) column experiments have shown that simultaneous $\mathrm{U}(\mathrm{VI}) / \mathrm{Fe}(\mathrm{III})$ reducing conditions can be maintained for 70 days of biostimulation under low sulfate conditions (Moon et al., 2007; Komlos et al., 2008) with virtually all of the uranium immobilized as U(IV) (Komlos et al., 2008). However, it is unclear how long $\mathrm{Fe}(\mathrm{III})$ reducing conditions can be maintained under these operating conditions (i.e., how long the "bioavailable" $\mathrm{Fe}(\mathrm{III})$ will last), which $\mathrm{Fe}(\mathrm{III})$ phases (e.g., ferrihydrite, goethite, silicate $\mathrm{Fe}(\mathrm{III})$, etc.) are preferentially reduced with time, and which biotransformed phases are formed. In addition, little research has been performed to determine how the microbial community changes over time during long-term biostimulation when sulfate levels are low, and if over time the electron donor flux shifts away from $\mathrm{U}(\mathrm{VI})$ reducing organisms to organisms that are not involved in the reduction of U(VI). Quantification of these processes could provide a better understanding of how the microbial community reacts to changes that may occur during biostimulation (e.g., loss of bioavailable $\mathrm{Fe}(\mathrm{III})$, biostimulation byproduct accumulation, etc.) and may help to improve current uranium biostimulation methods.

It is well known that precipitated U(IV) can be reoxidized to $\mathrm{U}(\mathrm{VI})$ (and remobilized back into the groundwater) in the presence of oxygen ( $\mathrm{Gu}$ et al., 2005; Moon et al., 2007; Komlos et al., 2008) and nitrate (Senko et al., 2002; Moon et al., 2007), thus making the post-stimulation management of bioprecipitated U(IV) more challenging. Therefore, in addition to maximizing uranium removal from groundwater during biostimulation, it is also important to understand how easily the reduced uranium can be remobilized (i) when biostimulation is terminated and an oxidant is reintroduced to the bioreduced zone (either from upgradient groundwater transport or oxygenated rainwater infiltration), (ii) during short-term pulses of an oxidant such as may occur during heavy infiltration events in shallow aquifers, or (iii) during short-term operational disruptions in electron donor addition.

Although secondary products of iron and sulfate reduction (e.g., mackinawite $\left[\mathrm{FeS}_{0.9}\right]$ ) have been shown to partially protect $\mathrm{U}(\mathrm{IV})$ from oxidation (Abdelouas et al., 1999b), little research has been performed on uranium reoxidation when sulfate reducing conditions are not important. The addition of synthetic $\mathrm{Fe}(\mathrm{II})\left(\mathrm{FeCl}_{2}\right)$ has been shown to significantly decrease uranium remobilization when exposed to oxygen in batch experiments (Zhong et al., 2005), which was attributed to the formation of hydrous ferric oxides upon reoxidation which provided sorption sites for the oxidized U(VI). However, Fe(III)/U(VI) reduction byproducts did not significantly protect $\mathrm{U}(\mathrm{IV})$ from reoxidation under field-relevant conditions using $\mathrm{Fe}(\mathrm{III})$ from natural sediment during short-term reoxidation experiments with either oxygen or nitrate (Moon et al., 2007; Komlos et al., 2008). It is unknown if extending the time of biostimulation during iron reducing conditions may produce an increased amount of solid phase $\mathrm{Fe}(\mathrm{II})$ and/or biomass buildup that could be a significant sink for oxygen and thus protect/slow U(IV) from reoxidation. Furthermore, it is unknown how the microbial community would change during short-term stoppage of electron donor addition during field-scale bioremediation. Short-term changes in electron donor addition may be used to control biomass during bioremediation (Taylor and Jaffe, 1991), but for this strategy to be effective, the desired response of the overall biomass or community composition would have to be faster than the onset of $\mathrm{U}(\mathrm{IV})$ reoxidation.

The goal of this research was to quantify the geochemical and biological changes that occur during long-term uranium biostimulation and subsequent reoxidation in a low sulfate system with sediment containing various pools of bioavailable Fe-oxides and silicate $\mathrm{Fe}(\mathrm{III})$. This includes the long-term monitoring of $\mathrm{Fe}(\mathrm{III}) / \mathrm{U}(\mathrm{VI})$ reducing conditions and subsequent reoxidation to determine (i) how long the bioreduction of natural Fe(III) minerals can be maintained in the absence of sulfate as a competing electron acceptor, (ii) which Fe(III) phases (Fe-oxides, Fe(III)-silicates, etc.) are preferentially bioreduced over this time period, (iii) which biogenic Fe(II) products are formed, (iv) how changes in $\mathrm{Fe}(\mathrm{III})$ bioavailability affect the U(VI) reduction efficiency with time, (v) how the microbial structure and corresponding electron donor utilization changes with time, and (vi) how short-term pulses of an oxidant affect the microbial community structure and the U(IV) stability. The experimental system involved four sediment columns operated under field-relevant flow conditions for $>200$ days of acetate biostimulation under low sulfate conditions. The biostimulation experiments were then followed by reoxidation of the reduced sediments with oxygen. One of the four columns was sacrificed periodically during biostimulation and reoxidation, allowing for changes in the solid phase associated $\mathrm{Fe}, \mathrm{U}$ and microbial community distribution to be observed with time (with the assumption that the biogeochemical changes with time were similar for each column since each column was operated under identical conditions). 


\section{MATERIALS AND METHODS}

\subsection{Column design and operation}

Four $15 \mathrm{~cm}$ long, $4.8 \mathrm{~cm}$ diameter glass column (Kimble Kontes) were wet packed with $454( \pm 22) \mathrm{g}$ of sediment from the background area of a former uranium processing site at Old Rifle, Colorado (a Uranium Mill Tailings Remedial Action (UMTRA) site part of the US Department of Energy's (DOE's) Environmental Remediation Sciences Program). This sediment was designated Rifle Area Background Sediment (RABS). A $20 \mu \mathrm{m}$ filter was located at both ends of each column. A description of this site can be found in Anderson et al. (2003). The previously saturated sediment was dried, sieved $(<2 \mathrm{~mm})$, and stored at $4{ }^{\circ} \mathrm{C}$ before use. Characteristics of the sediment are provided in Table 1 as well as Moon et al. (2007). After packing, the columns were flushed with $30 \mathrm{mM}$ bicarbonate until no uranium was detected at the effluent.

The columns were supplied with a $30 \mathrm{mM}$ bicarbonate buffered solution containing $20 \mu \mathrm{M}$ uranyl acetate (made from depleted uranium U-238, International Bio-analytical Industries, www.ibilabs.com), $0.14 \mathrm{mM} \mathrm{NH}_{4} \mathrm{Cl}, 0.014 \mathrm{mM}$ $\mathrm{NaH}_{2} \mathrm{PO}_{4} \cdot \mathrm{H}_{2} \mathrm{O}, 0.045 \mathrm{mM} \mathrm{KCl}$, and trace vitamins and minerals [Moon et al. (2007) adapted from Lovley and Phillips (1988)] up-flow through the column at a rate of $0.2 \mathrm{~mL} /$ min for 14 day prior to biostimulation. Included in the minerals was $9 \mu \mathrm{M}$ sulfate. Residence time of the columns was measured to be $5.8 \mathrm{~h}$ using a conservative tracer (bromide). The influent media was continuously purged with $\mathrm{CO}_{2} / \mathrm{N}_{2}$ gas (20:80). Just before acetate addition, one pore volume containing $5 \times 10^{7}$ cells $/ \mathrm{mL}$ of Geobacter metallireducens was added to the column and flow was shut off for $18 \mathrm{~h}$. The growth culture was prepared by growing $G$. metallireducens on $10 \mathrm{mM}$ acetate and $50 \mathrm{mM}$ ferric citrate for 5 days in a bicarbonate buffered growth media prepared as previously described (Komlos and Jaffe, 2004). After 5 days, the growth culture was rinsed to remove aqueous $\mathrm{Fe}(\mathrm{II})$ by centrifuging (5900g) for $20 \mathrm{~min}$, anaerobically removing the supernatant and replacing with influent media purged with $\mathrm{CO}_{2} / \mathrm{N}_{2}$ gas (20:80). The cell concentration was measured via microscopic direct counts using $0.1 \%$ acridine orange as previously described (Brown et al., 2005). $G$. metallireducens was chosen because it is a U(VI) and Fe(III) reducing bacterium whose genus has been shown to be important at Old Rifle during acetate biostimulation/uranium bioreduction (Chang et al., 2005).

Biostimulation began by pumping acetate via syringe pump (KD Scientific) to the main influent line just before the column influent resulting in a concentration of $3 \mathrm{mM}$ after mixing with the influent media. The columns were biostimulated for 209 days before being reoxidized with a dissolved oxygen containing solution. Column reoxidation was performed by discontinuing acetate addition and purging the influent media with $\mathrm{O}_{2} / \mathrm{CO}_{2} / \mathrm{N}_{2}$ (20:20:60) gas. All columns were operated at $22-25^{\circ} \mathrm{C}$ until they were destructively sampled in an anaerobic glove box $\left(3: 97 \mathrm{H}_{2}: \mathrm{N}_{2}\right)$. A column was destructively sampled after 104 and 203 days of biostimulation as well as after 21 and 122 days of reoxidation. Each column was analyzed for solid phase $U$ and $\mathrm{Fe}$, as well as biomass concentrations along the length of the column.

\subsection{Analytical measurements}

Dissolved oxygen was measured using a Corning 317 dissolved oxygen (DO) meter fitted to an in-line sampling device attached to the effluent of the column. Anions (acetate, bromide, nitrite, nitrate, and sulfate) were analyzed using a Dionex DX500 ion chromatograph equipped with a CD25 conductivity detector and a Dionex IonPac AS14-4 mm column. Mn(II) and total Mn were extracted from sediment samples in $0.5 \mathrm{~N} \mathrm{HCl}$ (without and with $0.25 \mathrm{~N}$ hydroxylamine hydrochloride, respectively) for $24 \mathrm{~h}$ and detected using ion chromatograph with postcolumn mixing with 4-(2-pyridyiazo)resorcinol monosodium salt hydrate (Komlos et al., 2007). Influent and effluent $\mathrm{U}(\mathrm{VI})$ concentrations were analyzed using reversed phased chromatography coupled to postcolumn derivatization with the dye Arsenazo III (Sigma-Aldrich) as described by Lack et al. (2002). The uranium was extracted from the sediment by adding $2-3 \mathrm{~g}$ of sediment to $5 \mathrm{~mL}$ of $1 \mathrm{M} \mathrm{NaHCO}$ and letting the extraction proceed under aerobic conditions for four days. All anion, $\mathrm{Mn}$ and uranium samples were filtered $(0.2 \mu \mathrm{m})$ and stored at $4{ }^{\circ} \mathrm{C}$ until analyzed. Effluent $\mathrm{Fe}(\mathrm{II})$ concentrations were measured by adding $0.5 \mathrm{~mL}$ of effluent solution to $0.5 \mathrm{~mL}$ of $1 \mathrm{~N} \mathrm{HCl}$ and analyzed after $1 \mathrm{~h}$ extraction using ferrozine (Lovley and Phillips, 1987). Acid volatile sulfide (AVS) concentrations were determined as previously described (Ditoro et al., 1990). Solid phase associated $\mathrm{Fe}(\mathrm{II})$ was measured at the termination of the column experiments in an anaerobic glove box $\left(3 \% \mathrm{H}_{2}: 97 \%\right.$ $\mathrm{N}_{2}$ ) by adding $\sim 0.2 \mathrm{~g}$ of sediment to $5 \mathrm{~mL} 0.5 \mathrm{~N} \mathrm{HCl}$, extracting for $24 \mathrm{~h}$ (Kukkadapu et al., 2006; Komlos et al., 2007) and detecting as described above. $\mathrm{HCl}$ extractable $\mathrm{Fe}(\mathrm{III})$ in the pristine sediment was determined as the difference between the $1 \mathrm{~h} 0.5 \mathrm{~N} \mathrm{HCl}$ extractable $\mathrm{Fe}(\mathrm{II})$ concentration (as described above, except $1 \mathrm{~h}$ extraction) and the $1 \mathrm{~h} \mathrm{HCl}$ extractable $\mathrm{Fe}$ concentration (same method as for $\mathrm{Fe}(\mathrm{II})$ except with $0.25 \mathrm{~N}$ hydroxylamine hydrochlo-

Table 1

Mineralogy of pristine Rifle Area Background Sediment (RABS)

\begin{tabular}{|c|c|c|c|c|}
\hline & Aluminum $(\mu \mathrm{mol} / \mathrm{g})$ & Silicon $(\mu \mathrm{mol} / \mathrm{g})$ & Manganese $(\mu \mathrm{mol} / \mathrm{g})$ & Iron $(\mu \mathrm{mol} / \mathrm{g})$ \\
\hline $\mathrm{HCl}$ extraction $(n=3)$ & * & * & $2.4 \pm 0.2$ & $2.3 \pm 0.04$ \\
\hline Hydroxylamine $\mathrm{HCl}$ extraction $(n=3)$ & $3.6 \pm 0.5$ & $5.4 \pm 1.2$ & $2.2 \pm 0.1$ & $9.5 \pm 0.6$ \\
\hline Ammonium oxalate $(n=3)$ & $5.9 \pm 0.1$ & $10.0 \pm 1.2$ & $1.2 \pm 0.1$ & $5.2 \pm 0.2$ \\
\hline Total dissolution $(n=2)$ & $*$ & $*$ & $*$ & $533 \pm 12$ \\
\hline
\end{tabular}

* Analysis not performed. 
ride) (Anderson et al., 1998). Extractable oxides were determined using methods previously described (Zachara et al., 1998). These methods included hydroxylamine hydrochloride for amorphous $\mathrm{Fe}(\mathrm{III})$ oxyhydroxides and reducible $\mathrm{Mn}(\mathrm{III} / \mathrm{IV})$-oxides, and acidified ammonium oxalate for poorly crystalline $\mathrm{Fe}(\mathrm{III})$-oxides. Inductively-coupled plasma spectroscopy (ICP) was used to analyze aluminum, manganese and silica concentrations. The total Fe content was determined via total dissolution by fusing the sediment at $950{ }^{\circ} \mathrm{C}$ at a ratio of $1: 3$ with $\mathrm{Li}$-metaborate followed by diluting in $5 \% \mathrm{HNO}_{3}$ and quantifying using the standard addition method (Harris, 1999).

\subsection{Phospholipid fatty acid analysis (PLFA)}

PLFA analysis was performed using previously reported precautions (White and Ringelberg, 1998). Sediment samples $(5 \mathrm{~g})$ were extracted with the single-phase chloroform-methanol-buffer system of Bligh and Dyer (1959), as modified by White et al. (1979). The total lipid extract was fractionated into neutral lipids, glycolipids, and polar lipids by silicic acid column chromatography (Guckert et al., 1985). The polar lipids were transesterified to the fatty acid methyl esters (FAMEs) by a mild alkaline methanolysis (Guckert et al., 1985).

The FAMEs were analyzed by capillary gas chromatography with flame ionization detection on a Hewlett-Packard 5890 Series 2 chromatograph with a $50 \mathrm{~m}$ non-polar column $(0.2 \mathrm{~mm}$ I.D., $0.11 \mu \mathrm{m}$ film thickness). Preliminary peak identification was by comparison of retention times with known standards. Definitive identification of peaks was accomplished by gas chromatography/mass spectroscopy of selected samples using a Hewlett-Packard 6890 series gas chromatograph interfaced to a 5973 mass selective detector using a $20 \mathrm{~m}$ non-polar column (0.1 mm I.D., $0.1 \mu \mathrm{m}$ film thickness). Fatty acids were named according to the convention of Gunstone and Herslöf (1992).

\subsection{Quantitative polymerase chain reaction (Q-PCR) analysis}

DNA was extracted from sediment samples $(\sim 0.5 \mathrm{~g}$ each) using the FastDNA spin kit for soil (BIO101, USA) and eluted in $100 \mu \mathrm{L} \mathrm{1/10} \mathrm{TE} \mathrm{buffer.} \mathrm{All} \mathrm{Q-PCR} \mathrm{was} \mathrm{per-}$ formed by Microbial Insights Inc. (Rockford, TN). Each $30 \mu \mathrm{L}$ TaqMan based PCR assay contained DNA template, $1 \times$ TaqMan Universal PCR Master Mix (Applied Biosystems), TaqMan probe (100-500 nM) and forward and reverse primers $(300-1500 \mathrm{nM})$. TaqMan assays were performed on an ABI Prism 7300 Sequence Detection System (Applied Biosystems) with the following temperature program: $2 \mathrm{~min}$ at $50^{\circ} \mathrm{C}$ and $10 \mathrm{~min}$ at $95^{\circ} \mathrm{C}$, followed by 50 cycles of $15 \mathrm{~s}$ at $95^{\circ} \mathrm{C}$ and $1 \mathrm{~min}$ at $58^{\circ} \mathrm{C}$. The following groups of bacteria were targeted with the indicated TaqMan probe and forward/reverse primers, respectively: Eubacteria (TM1389, BACT1369/PROK1492R (Suzuki et al., 2000)); Iron- and sulfate-reducing bacteria (GBC2, 361F/685R (Stults et al., 2001)); and Geobacteraceae (GBC2, 561F/825R, (Stults et al., 2001)). Each $30 \mu \mathrm{L}$ SYBR green PCR assay contained DNA template, $1 \times$ clone PfuBuffer (Stratagene), $0.4 \mathrm{mM} \mathrm{MgCl} 2,0.2 \mathrm{mM}$ of each dNTP (Roche Applied Science), SYBR green (1:30,000 dilution, Molecular Probes), 1 U PfuTurbo HotStart DNA polymerase (Stratagene), DMSO $(0-0.5 \mu \mathrm{L})$, and forward and reverse primers (500-2500 nM). SYBR green assays were performed using an ABI Prism 7000 Sequence Detection System (Applied Biosystems) with temperature cycles varied based on primer set. SYBR green PCR was used to detect methanogens using the forward/reverse primers ME1F/ME2R (Hales et al., 1996). Calibrations were obtained using a serial dilution of positive control DNA. The Sequence Detector program subtracted background signal for each sample during cycles 3 through 15. The fluorescence threshold was computed as $10 \times$ the standard deviation of the background signal and the original concentration of DNA in each sample was determined by comparing the CT sample values with the calibration data. For each sequence assayed, a calibration curve was obtained by using a serial dilution of a known concentration of positive control DNA. The CT values that are obtained from each sample are then compared with the standard curve to determine the original sample DNA concentration. For the Q-PCR assay of Eubacteria, the positive control was Nitrosomonas europaea and amplification was for 40 PCR cycles, for methanogens it was Methanosarcina mazei and 30 cycles, and for Geobacter spp. and delta-proteobacteria it was $G$. metallireducens and 45 cycles. Gene copy numbers were calculated assuming $9.13 \times 10^{14} \mathrm{bp} / \mu \mathrm{g}$ DNA.

\subsection{Mössbauer spectroscopy}

Mössbauer analysis of the pristine sediment was performed on an air-dried sample, while those of biostimulated sediments were performed on samples that were dried in an anoxic chamber. The prepared Mössbauer disks were stored in anoxic chamber until analysis. Spectra were obtained at various temperatures, room temperature (RT) to $12 \mathrm{~K}$, and occasional spectra at liquid $\mathrm{He}(4.2 \mathrm{~K})$. Only spectra obtained at $12-\mathrm{K}$, where Fe-oxides and most of $\mathrm{Fe}(\mathrm{II})$-phases (e.g., siderite) magnetically order, were reported in this study. A closed-cycled cryostat (ARS, Allentown) was employed for low temperature measurements. Details of the Mössbauer instrumentation, sample preparation procedure, and guidelines for modeling were reported by Kukkadapu et al. (2004) and Kukkadapu et al. (2006). Measurements are carried out on single sub-samples; no replicate measurements since collection of reasonably good signal-to-noise ratio spectrum measurement is very time consuming. Mössbauer spectra of a magnetite/hematite mixture, isolated using a bar magnet from the pristine sediment, and synthetic goethite were obtained at $12 \mathrm{~K}$ and analyzed (not shown) so their derived parameters can be "plugged" into modeling of $12 \mathrm{~K}$ spectra reported in this study. This was done because parameters of Fe-oxides at $12 \mathrm{~K}$ are not available in literature. Despite this, due to trade-off of spectral areas between magnetite and hematite, it was not possible to obtain a unique solution for the magnetite and hematite areas. However, robust fits with reasonably good total Fe-oxide (sextet) to silicate Fe (doublet) 
ratios were possible. The coefficient of variation of the spectral areas of the individual sites generally ranged from $1 \%$ to $2 \%$.

\section{RESULTS AND DISCUSSION}

\subsection{Fe characterization of initial sediment}

The total $\mathrm{Fe}$ content in the sediment was measured to be $533 \mu \mathrm{mol} / \mathrm{g}$ (or $2.93 \mathrm{wt} \%$ of the sediment, Table 1 ). The initial sediment contained $9.5 \mu \mathrm{mol} / \mathrm{g}$ of hydroxylamine hydrochloride extractable $\mathrm{Fe}$, which is operationally defined as amorphous Fe-oxide content (Chao and Zhou, 1983); $5.2 \mu \mathrm{mol} / \mathrm{g}$ ammonium oxalate extractable Fe, which is operationally defined as the poorly crystalline Fe-oxide content (Schwertmann, 1959); and $7.2 \mu \mathrm{mol} / \mathrm{g} 0.5 \mathrm{~N} \mathrm{HCl}$ (1-h extraction) $\mathrm{Fe}(\mathrm{III})$, which is operationally defined as "bioavailable" Fe (Lovely and Phillips, 1986) (Table 1). These Fe concentrations made up $\sim 1 \%$ of the total Fe concentration $(533 \mu \mathrm{mol} / \mathrm{g})$ Additional characterization using Mössbauer measurements at various temperatures and powder XRD of the clay fraction showed that over half $(56 \%)$ of the sediment iron was associated with clays (montmorillonite, muscovite and clinochlore) with a clay $\mathrm{Fe}(\mathrm{II}) /$ $\mathrm{Fe}(\mathrm{III})$ ratio of 1.0. The remaining $\mathrm{Fe}$ was in the form Alsubstituted goethite $(28 \%)$, hematite $(9 \%)$, and magnetite (7\%). A modeled Mössbauer spectrum of the $<2$-mm size fraction of the pristine sample, along with various biostimu- lated samples, at $12 \mathrm{~K}$ showing peaks due to various phases is shown in Fig. 1.

\subsection{Biostimulation}

Prior to acetate addition, effluent U(VI) concentrations equaled influent U(VI) concentrations (Fig. 2, inset). Com-

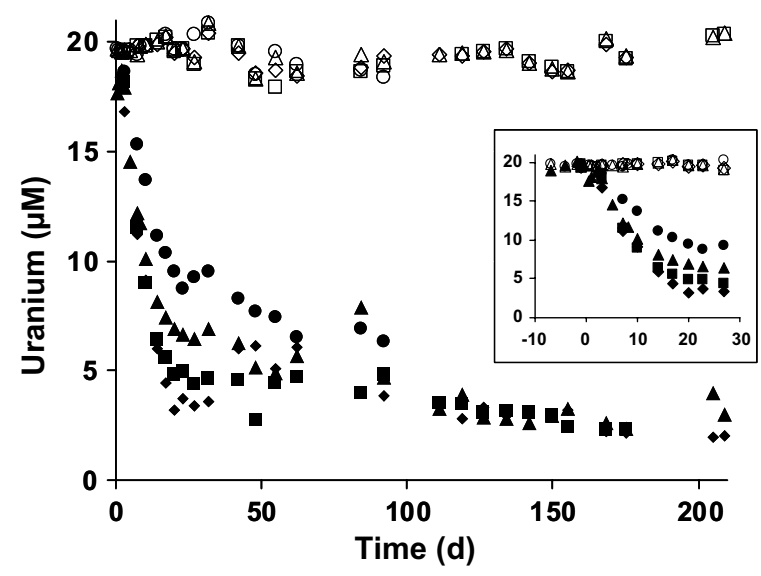

Fig. 2. Influent (open symbols) and effluent (closed symbols) uranium concentration during biostimulation. Four columns were run in parallel and different symbols represent different columns. Inserted graph shows the uranium concentrations just before and after biostimulation commenced.

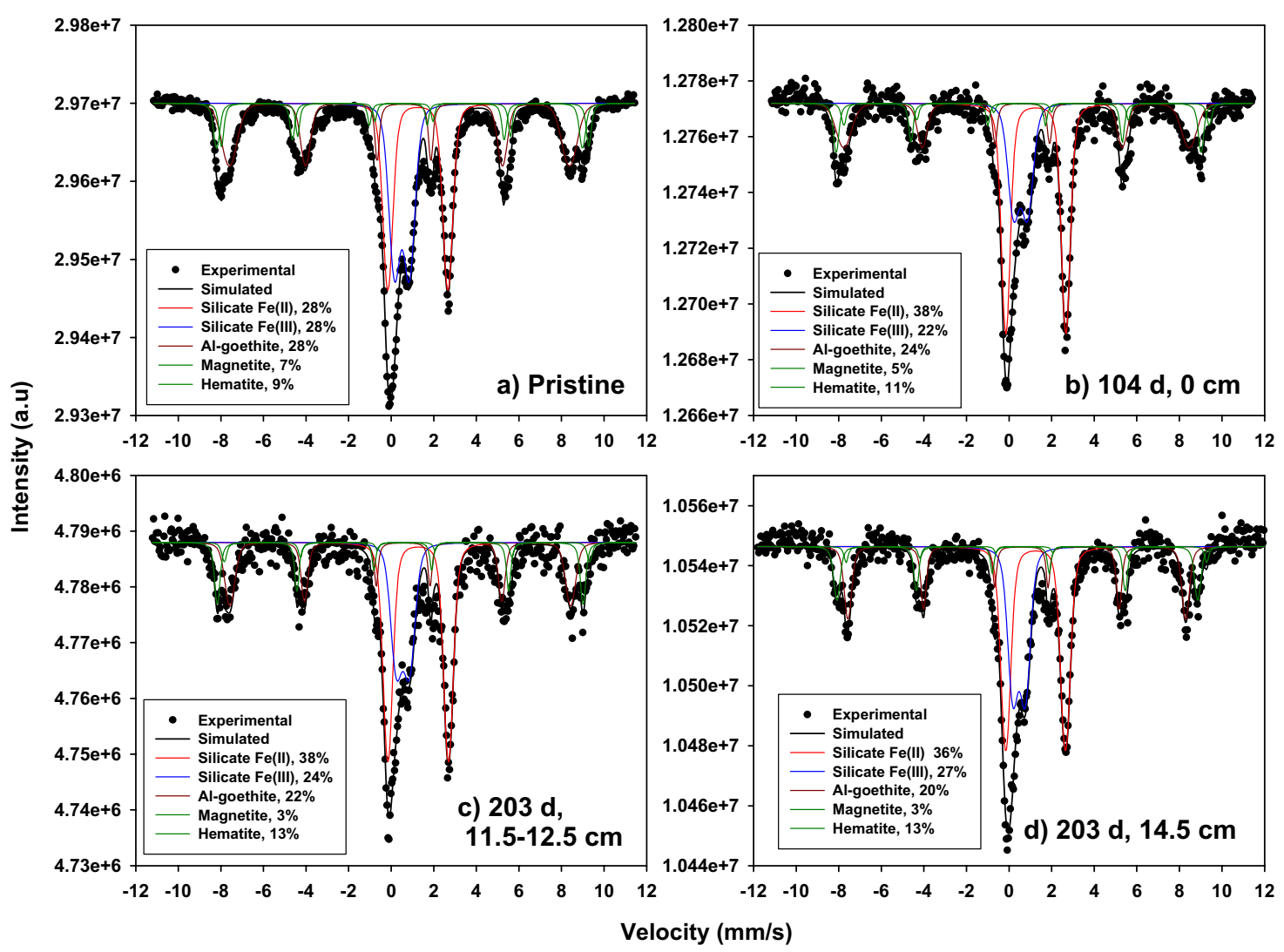

Fig. 1. Mossbauer spectra of the (a) pristine sediment, (b) biostimulated sediment (104 day, $0 \mathrm{~cm})$, (c) biostimulated sediment (203 day, $11.5 \mathrm{~cm})$, and (d) biostimulated sediment (203 day, $14 \mathrm{~cm})$. 


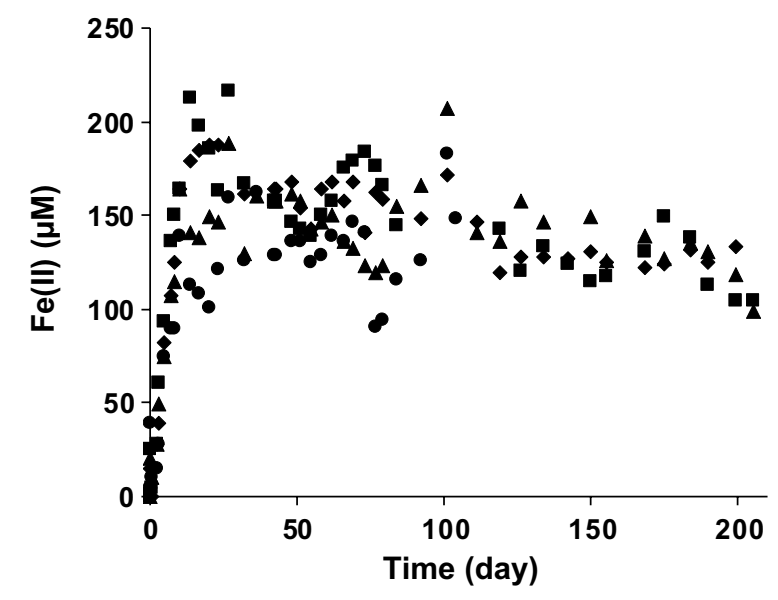

Fig. 3. Effluent $\mathrm{Fe}(\mathrm{II})$ concentrations during biostimulation. Four columns were run in parallel and each symbol represents a different column.

mencement of acetate addition resulted in U(VI) precipitation (Fig. 2) occurring simultaneously with Fe(III) reduction (Fig. 3). U(VI) immobilization efficiency continued to increase throughout biostimulation with $88 \%$ removal of the influent $20 \mu \mathrm{M}$ U(VI) concentration after 209 days. XANES analysis performed on a separate flowing column using the same RABS sediment under identical flow conditions and supplied the same simulated groundwater showed that the majority $(>90 \%)$ of the U precipitated after 70 days of bioreduction was in the form of U(IV) (Komlos et al., 2008) showing that the $U$ precipitated under these conditions is in its reduced form [U(IV)].

$\mathrm{Fe}$ (III) reducing conditions continued over 200 days (reducible $\mathrm{Fe}(\mathrm{III})$ in the sediment was not exhausted) (Fig. 3) and, unlike U(VI) reduction efficiency (which increased with time, Fig. 2), the Fe(III) reduction (measured in terms of $\mathrm{Fe}(\mathrm{II})$ concentration in the effluent) gradually decreased with time (Fig. 3). Even though the Fe(II) production decreased with time, effluent $\mathrm{Fe}(\mathrm{II})$ concentrations only decreased $\sim 30 \%$ over the final 100 days of the experiment (Fig. 3). During this time the effluent acetate concentration decreased from $0.8 \mathrm{mM}$ ( $26 \%$ of influent acetate) to $0.2 \mathrm{mM}(7 \%$ of influent acetate).

One of the four columns was destructively sampled approximately half way through biostimulation (day 104) and another at the end of biostimulation (day 203). Uranium precipitation was relatively uniform after 104 days of biostimulation (Fig. 4a). After 203 days of biostimulation, the uranium concentrations were higher than they were after 104 days and the majority of the uranium precipitation between day 104 and day 203 occurred at the beginning of the column (Fig. 4a). Unlike uranium, there was little change in solid phase associated $\mathrm{Fe}$ (II) between day 104 and 203 (Fig. 4b). In addition, $\mathrm{Fe}(\mathrm{II})$ concentrations increased from the beginning to the end of the column (Fig. 4b). The spike in solid phase $\mathrm{Fe}(\mathrm{II})$ and uranium concentrations at the end of the columns (Fig. 4a and b) has been observed in previous column experiments (Moon et al., 2007) and it is speculated to be an artifact of the column caused by suspended par-
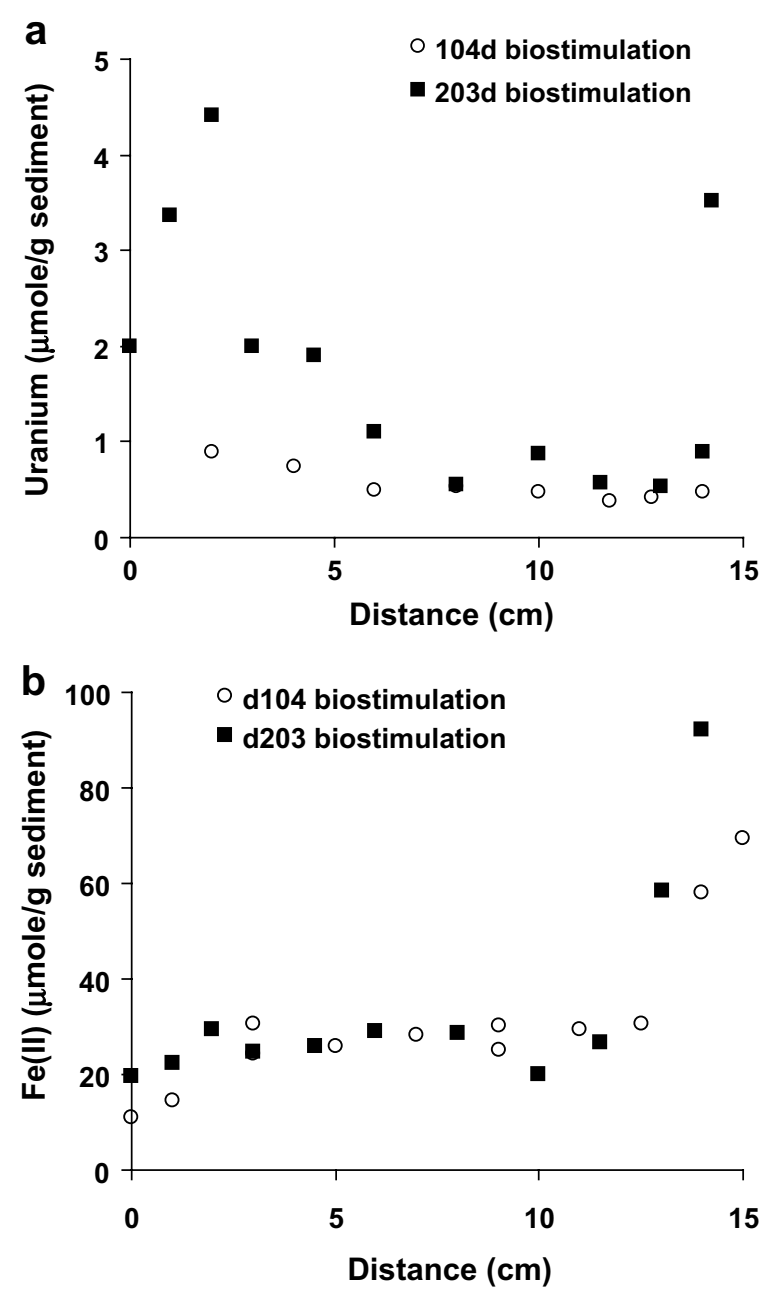

Fig. 4. Solid phase (a) uranium and (b) Fe(II) concentrations along the length of column during biostimulation.

ticles being filtered out due to the $20 \mu \mathrm{m}$ filter at the end of the columns.

The amount of $\mathrm{Fe}(\mathrm{II})$ bioproduced (solid phase + exported) after 203 days (17.5 mmol, Table 2) was $7.7 \%$ of the total amount of $\mathrm{Fe}$ in the sediment ( $424 \mathrm{~g}$ sediment in column $\times 533 \mu \mathrm{mol} \mathrm{Fe} / \mathrm{g}$ [Table 1] = $226 \mathrm{mmol}$ ). Twentysix percent of the biogenic $\mathrm{Fe}(\mathrm{II})$ was advectively transported out of the column by day 104 with the remainder associated with the sediment (reduced iron in clay lattice and/or iron precipitates) (Table 2). The cumulative fraction of $\mathrm{Fe}$ (II) exported increased to $42 \%$ after 203 days of biostimulation, with little additional accumulation of solid phase $\mathrm{Fe}(\mathrm{II})$ after day 104 (Fig. 4b). The total Fe-oxide reduction/ consumption (as measured by the cumulative change in the goethite, hematite, and magnetite fraction of Fe in the sediment from $12 \mathrm{~K}$ Mössbauer spectra, Fig. 1) decreased from $44 \%$ (pristine) to $36 \%$ (203 day $14.5 \mathrm{~cm}$ ), which corresponds to a total of $6.8 \mathrm{mmol} \mathrm{Fe-oxides} \mathrm{consumed} \mathrm{during} \mathrm{biosti-}$ mulation. Similar percent distribution was also obtained at $4.2 \mathrm{~K}$ (not shown). This loss of Fe-oxides agreed fairly well with the amount of Fe cumulatively measured at the effluent of the column ( $7 \mathrm{mmol}$, Table 2 ). There was slight discrepancy in relative distribution of various phases mea- 
Table 2

Mass of $\mathrm{Fe}(\mathrm{II})$ produced in each column after different times during biostimulation

\begin{tabular}{llllll}
\hline $\begin{array}{l}\text { Length of } \\
\text { biostimulation }\end{array}$ & $\begin{array}{l}\text { Solid phase Fe(II) } \\
(\mathrm{mmol})\end{array}$ & $\begin{array}{l}\text { Exported Fe(II) } \\
(\mathrm{mmol})\end{array}$ & $\begin{array}{l}\text { Total Fe(II) produced } \\
(\mathrm{mmol})\end{array}$ & \% Solid phase & \% Exported \\
\hline 104 day & 10.8 & 3.7 & 14.5 & 74 & 26 \\
203 day & 10.2 & 7.3 & 17.5 & 58 & 42 \\
\hline
\end{tabular}

Solid phase $\mathrm{Fe}(\mathrm{II})$ and exported $\mathrm{Fe}(\mathrm{II})$ was calculated from the area under the curve of Figs. $4 \mathrm{~b}$ and 2, respectively.

sured at different locations in the column (Fig. 1c and d). This could have been due to sample heterogeneity. Mössbauer peaks due to $\mathrm{Fe}(\mathrm{II})$-phases that are expected under the geochemical conditions such as siderite and/or mackinawite $\left(\mathrm{FeS}_{0.9}\right)$ were not evident in the $12 \mathrm{~K}$ Mössbauer spectra. Siderite and mackinawite display sextet peaks with features very different from Fe-oxides (Murad and Cashion, 2004). Mass balance calculations clearly indicated that the increase in $\mathrm{Fe}(\mathrm{II})$ doublet upon biostimulation was mainly due to reduction of silicate $\mathrm{Fe}(\mathrm{III})$, which is evident from increase in silicate $\mathrm{Fe}(\mathrm{II}) / \mathrm{Fe}(\mathrm{III})$ ratio from 1.0 (pristine sediment) to 1.4-1.7 (biostimulated sediments) (Fig. 1). Sulfate removal between the influent and effluent of the column did occur but, due to the relatively low influent sulfate concentration $[9 \mu \mathrm{M}$, compared to $6-9 \mathrm{mM}$ at the Old Rifle field site (Anderson et al., 2003)], acid volatile sulfide (AVS) concentrations were low (below $1.8 \mu \mathrm{mol} / \mathrm{g}$ ) after 203 days of biostimulation. This chemical data implies that the inner doublet was mainly due to silicate Fe(III) with little or no contribution from low-spin $\mathrm{Fe}(\mathrm{II})$ diamagnetic pyrite $\left(\mathrm{FeS}_{2}\right)$ which exhibits doublet peaks similar to those of high-spin $\mathrm{Fe}(\mathrm{III})$ compounds such as Fe in silicates (Murad and Cashion, 2004). Overall, Mössbauer analysis showed that goethite/Fe-oxide content decreased gradually throughout biostimulation. Also, the cessation of both $\mathrm{Fe}(\mathrm{III})$-clay reduction (Fig. 1a and b) and solid phase $\mathrm{Fe}(\mathrm{II})$ buildup (Fig. 4b) after day 104 of biostimulation indicates that biogenic $\mathrm{Fe}(\mathrm{II})$ produced from $\mathrm{Fe}(\mathrm{III})$-clay is not mobile (also observed by Komlos et al. (2007) for a different sediment). Bioreduction of silicate $\mathrm{Fe}(\mathrm{III})$ and goethite was in agreement with recent work on reduction of silicate Fe(III) (e.g., Jaisi et al., 2005; Komlos et al., 2007) and soil goethites (e.g., Kukkadapu et al., 2001).
The theoretical amount of electrons transferred to $\mathrm{Fe}(\mathrm{III}), \mathrm{U}(\mathrm{VI})$, and $\mathrm{SO}_{4}{ }^{2-}$ was only a small percentage $(<2 \%)$ of the electrons transferred from acetate consumption after 104 and 203 days of biostimulation (Table 3). Therefore, $>98 \%$ of the electrons transferred from acetate went to processes other than $\mathrm{Fe}(\mathrm{III}), \mathrm{U}(\mathrm{VI})$ and $\mathrm{SO}_{4}{ }^{2-}$ reduction after 104 days of biostimulation. Mn-oxides were not detected in the initial sediment (Table 1) indicating that $\mathrm{Mn}$ reduction can also be neglected. The total cells in the column, based on the cumulative bacteria and methanogen populations from the Q-PCR analysis, after 104 days and 203 days of biostimulation, was $1.0 \times 10^{10}$ and $1.4 \times 10^{11}$ cells, respectively. These values were calculated by taking the sum of the estimated total cell numbers at different sections of the column based on the actual values presented in Fig. 5 and the estimated mass of sediment in each section. An order of magnitude increase in non$\mathrm{Fe}(\mathrm{III}) / \mathrm{U}(\mathrm{VI})$ bacteria between day 104 and 203 would result in increased acetate consumption by these non-uranium and iron reduction processes, thus potentially decreasing the volume of the aquifer that could be biostimulated over time and thus negatively impacting the active uranium bioremediation zone.

The minimal impact of $\mathrm{Fe}(\mathrm{III}), \mathrm{U}(\mathrm{VI})$, and $\mathrm{SO}_{4}{ }^{2-}$ reduction on acetate utilization corresponds with Q-PCR data (Fig. 6) showing that members of the delta-proteobacteria (which include Geobacter as well as other (but not all) iron reducers, and most sulfate reducers) comprised less than $1 \%$ of the sediment-associated total biomass after 104 and 203 days of biostimulation. The delta-proteobacteria and Geobacter population remained relatively constant between day $104\left(6.1 \times 10^{6}\right.$ and $2.2 \times 10^{6}$ cells, respectively) and day $203\left(7.0 \times 10^{6}\right.$ and $1.5 \times 10^{6}$ cells, respectively). However,

Table 3

Summary of electron transferred at day 104 and 203 of biostimulation for the oxidation of acetate and the reduction of Fe(III), U(VI) and $\mathrm{SO}_{4}{ }^{2-}$

\begin{tabular}{|c|c|c|c|c|c|c|}
\hline & \multicolumn{3}{|l|}{ Day 104 of biostimulation } & \multicolumn{3}{|l|}{ Day 203 of biostimulation } \\
\hline & $\begin{array}{l}\text { Consumed/produced per } \\
\text { residence time }(\mu \mathrm{mol} / \mathrm{L} / \mathrm{h})\end{array}$ & $\begin{array}{l}\text { e-transferred } \\
(\mu \mathrm{mol} / \mathrm{L} / \mathrm{h})\end{array}$ & $\begin{array}{l}\text { e-accepted from } \\
\text { donor }(\%)\end{array}$ & $\begin{array}{l}\text { Consumed/produced per } \\
\text { residence time }(\mu \mathrm{mol} / \mathrm{L} / \mathrm{h})\end{array}$ & $\begin{array}{l}\text { e-transferred } \\
(\mu \mathrm{mol} / \mathrm{L} / \mathrm{h})\end{array}$ & $\begin{array}{l}\text { e-accepted from } \\
\text { donor }(\%)\end{array}$ \\
\hline Acetate consumed & 431.7 & $3453.7^{\mathrm{a}}$ & & 541.0 & 4328.3 & \\
\hline $\mathrm{Fe}(\mathrm{II})$ produced & 35.2 & $35.2^{\mathrm{b}}$ & 1.0 & 22.0 & 22.0 & 0.51 \\
\hline $\mathrm{U}(\mathrm{VI})$ reduced & 2.7 & $5.5^{\mathrm{c}}$ & 0.2 & 3.2 & 6.4 & 0.15 \\
\hline $\mathrm{SO}_{4}{ }^{2-}$ reduced & 1.4 & $10.9^{\mathrm{d}}$ & 0.3 & 1.6 & 12.5 & 0.29 \\
\hline Sum of acceptors & & 51.6 & 1.5 & & 40.9 & 1.0 \\
\hline \multicolumn{7}{|c|}{ a $\frac{1}{4} \mathrm{CO}_{2}+\frac{7}{8} \mathrm{H}^{+}+\mathrm{e}^{-}=\frac{1}{8} \mathrm{CH}_{3} \mathrm{COO}^{-}+\frac{1}{4} \mathrm{H}_{2} \mathrm{O}$ (Morel and Hering, 1993). } \\
\hline \multicolumn{7}{|c|}{${ }^{\mathrm{b}} \mathrm{Fe}^{3+}+\mathrm{e}^{-}=\mathrm{Fe}^{2+}$ (Morel and Hering, 1993). } \\
\hline \multicolumn{7}{|c|}{${ }^{\mathrm{c}} \frac{1}{2} \mathrm{UO}_{2}(\mathrm{~s})+\mathrm{HCO}_{3}^{-}=\frac{1}{2} \mathrm{UO}_{2}\left(\mathrm{CO}_{3}\right)_{2}{ }^{2-}+\mathrm{H}^{+}+\mathrm{e}^{-}$(Abdelouas et al., 1} \\
\hline \multicolumn{7}{|c|}{ d $\frac{1}{8} \mathrm{SO}_{4}^{2-}+\frac{5}{4} \mathrm{H}^{+}+\mathrm{e}^{-}=\frac{1}{8} \mathrm{H}_{2} \mathrm{~S}(\mathrm{aq})+\frac{1}{2} \mathrm{H}_{2} \mathrm{O}$ (Morel and Hering, 1993). } \\
\hline
\end{tabular}



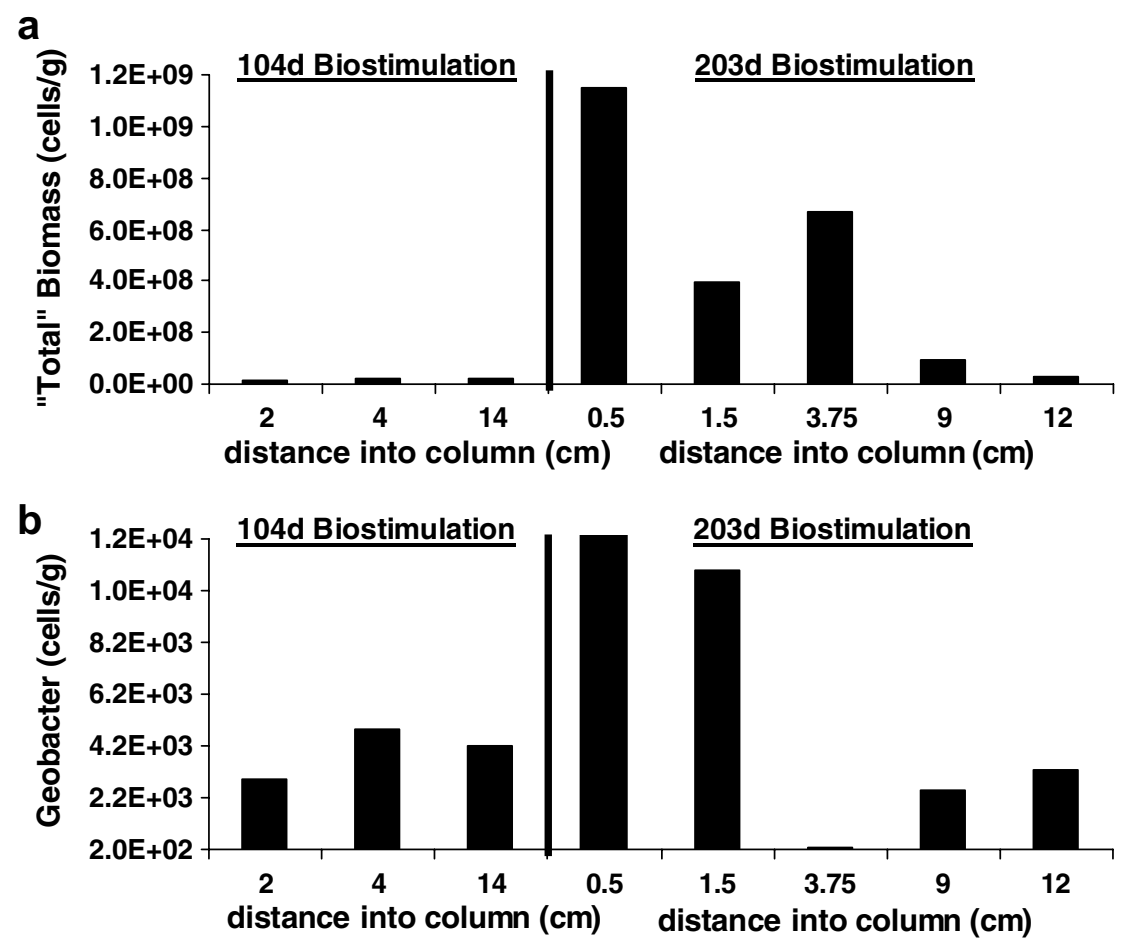

Fig. 5. (a) Estimated total biomass and (b) Geobacter concentrations after 104 and 203 day of biostimulation using Q-PCR. Total biomass was estimated from the sum of the bacteria and methanogen populations.

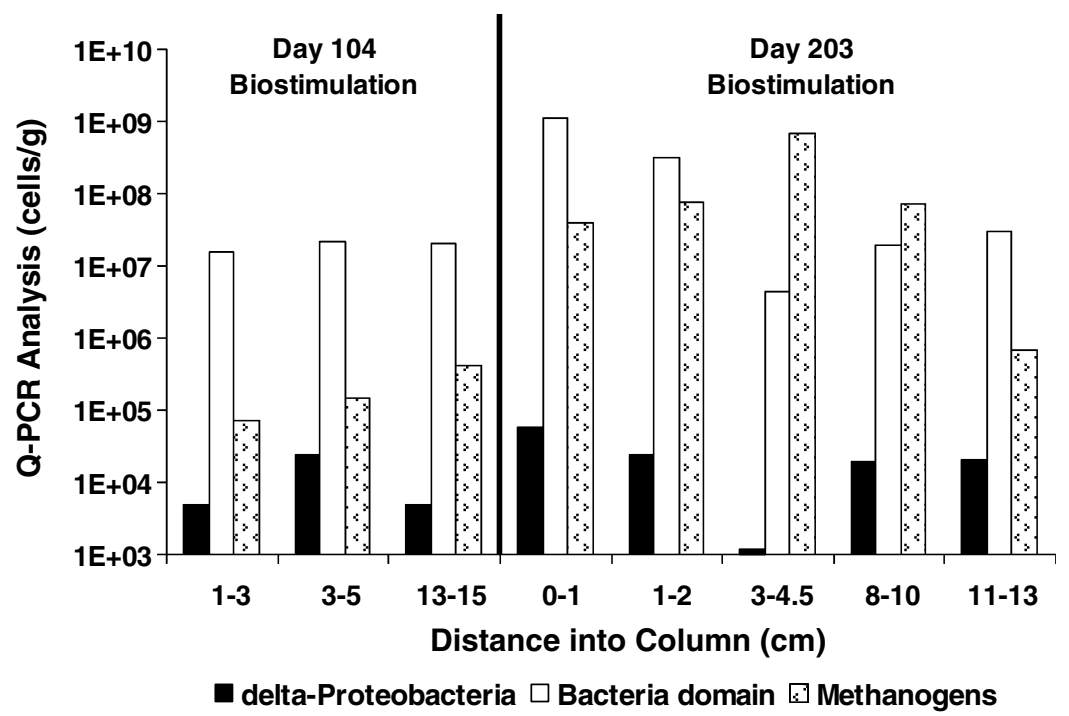

Fig. 6. Q-PCR community structure throughout the column after 104 and 203 days of biostimulation. The delta-proteobacteria population includes iron/uranium reducers (including Geobacter) and most sulfate reducers (Madigan et al., 1996) although not all iron/uranium reducing organism are delta-proteobacteria. The Bacteria domain includes delta-proteobacteria but not methanogens (which are part of the Archaea domain).

there was almost a three order of magnitude increase in the methanogen population in the column from day 104 $\left(1.1 \times 10^{8}\right.$ cells $)$ to day $203\left(8.6 \times 10^{10}\right.$ cells $)$. Methanogens went from less than $2 \%$ of the total population on day
104 to $99 \%$ in parts of the column on day 203 (Fig. 6) due to excess influent acetate well beyond the capacity of metal reduction. The combination of the Q-PCR analysis and the acetate/Fe(II)/U(VI) mass balance suggest that 
processes other than $\mathrm{U}(\mathrm{VI})$ and $\mathrm{Fe}(\mathrm{III})$ reduction are dominant in this system and that the majority of the electron flux is toward methanogens.

The distribution of PLFA (which is an indication of the bacterial composition) throughout the column after 104 days of biostimulation, though different than the pristine sediment, was relatively uniform with distance into the column (Fig. 7a). PLFA analysis showed an increase in the percent of monounsaturated PLFA between the pristine sediment and the sediment after 104 days of biostimulation (Fig. 7a). Monounsaturates are typically associated with Gram-negative bacteria (including Geobacter). After 203 days of biostimulation there was not only an increase in the total biomass at the beginning of the column (Fig. $5 a)$, but there was also a shift in the microbial community composition at the beginning of the column as evidenced by an increase in the monounsaturated PLFA percent composition and a decrease in the terminally-branched saturates (typically associated with Gram-positive bacteria) and mid-chain branched saturates (typically associated with actinomycetes and sulfate-reducing bacteria) (Fig. 7b). The
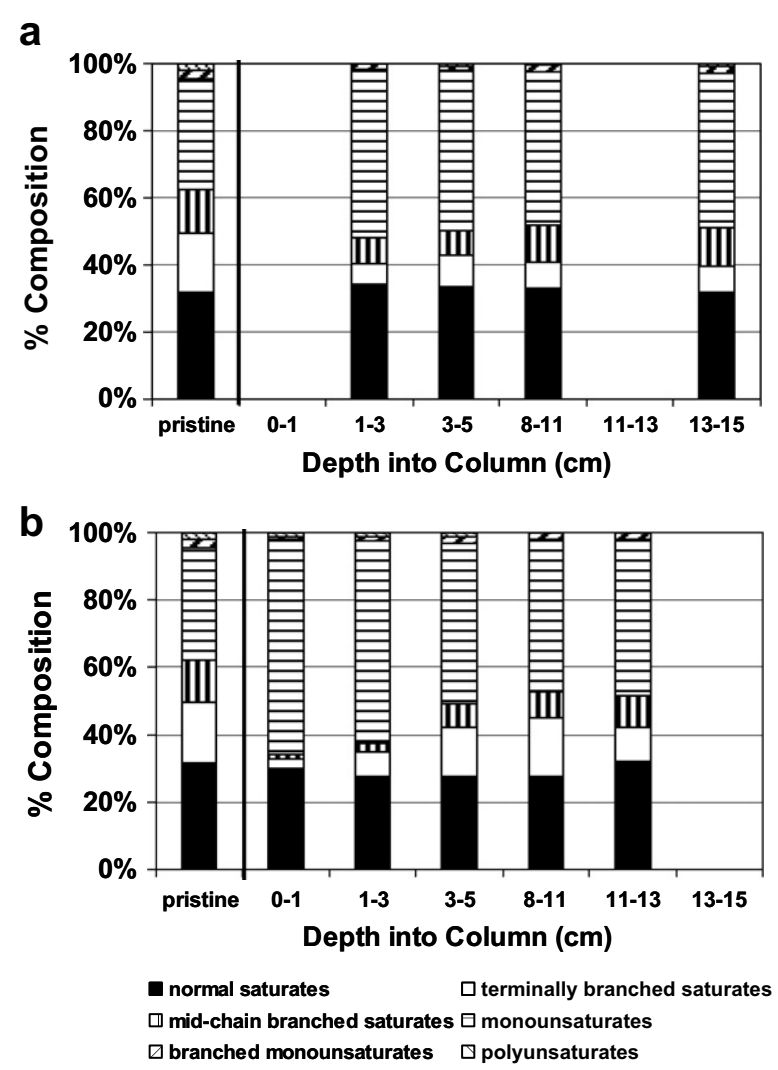

Fig. 7. PLFA community composition of pristine sediment (before bioaugmentation/biostimulation) and throughout the column after (a) 104 days and (b) 203 days. The relationship of the PLFA functional groups to the microbial community is as follows: normal saturated are ubiquitous, terminally-branched saturates are attributed to Gram-positive bacteria, mid-chained branched saturates and branched monounsaturates to actinomycetes and sulfatereducing bacteria, monounsaturates to Gram-negative bacteria and polyunsaturates to eukaryotes (White et al., 1996). increase in uranium reducers at the beginning of the column corresponded with the uranium reducing conditions (i.e., U(IV) precipitation) moving to the beginning of the column over long-term biostimulation (the change in community composition between day 104 and day 203 occurred even though there was little change in $\mathrm{Fe}(\mathrm{II})$ production (Fig. 3) and U(VI) utilization (Fig. 2) during that time). Further into the column, the trend in the bacterial community more closely resembled that observed before biostimulation began (Fig. 7). The PLFA analysis does not include methanogens, which are a major contributor to the microbial community as measured by Q-PCR (Fig. 6).

\subsection{Reoxidation}

Uranium reoxidation occurred very fast (Fig. 8a) when oxygen was introduced after biostimulation resulting in a very large uranium spike exiting the column (7-8 times higher than the original influent concentration) within the first 10 days of reoxidation. This resulted in $61 \%$ of the precipitated uranium to exit the column after only 21 days of

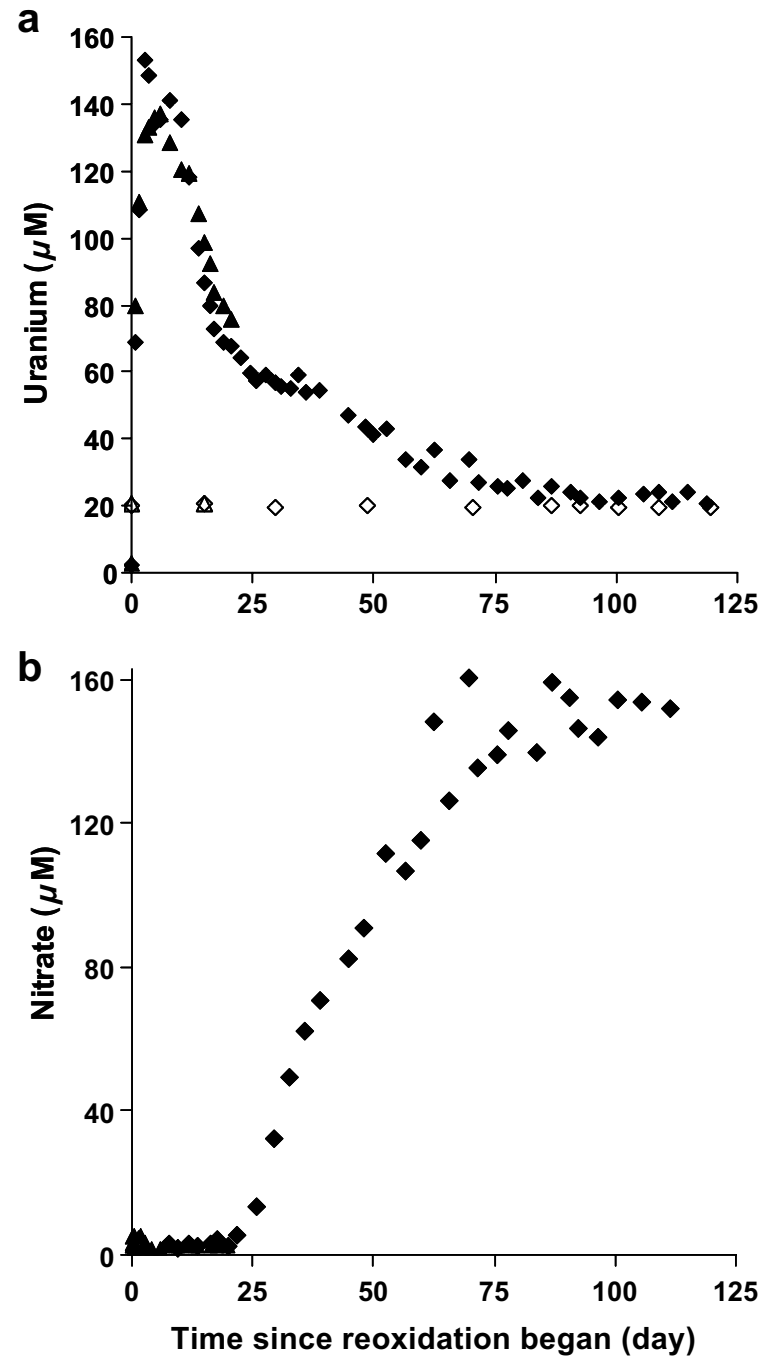

Fig. 8. Influent (open symbols) and effluent (closed symbols) (a) uranium and (b) nitrate concentrations during reoxidation. 
oxygen addition and virtually all exiting the column by day 122. The majority of the U(IV) oxidation by day 21 occurred within the first four cm of the column (Fig. 9a). After 122 days of reoxidation, little uranium was measured throughout the column (Fig. 9a) which corresponds with the effluent uranium concentration equaling the influent uranium concentrations after 100 days of reoxidation (Fig. 8a).

Loss of solid phase $\mathrm{Fe}(\mathrm{II})$ was detected at the beginning and end of the column after 21 days of reoxidation and throughout the column after 122 days of reoxidation (Fig.
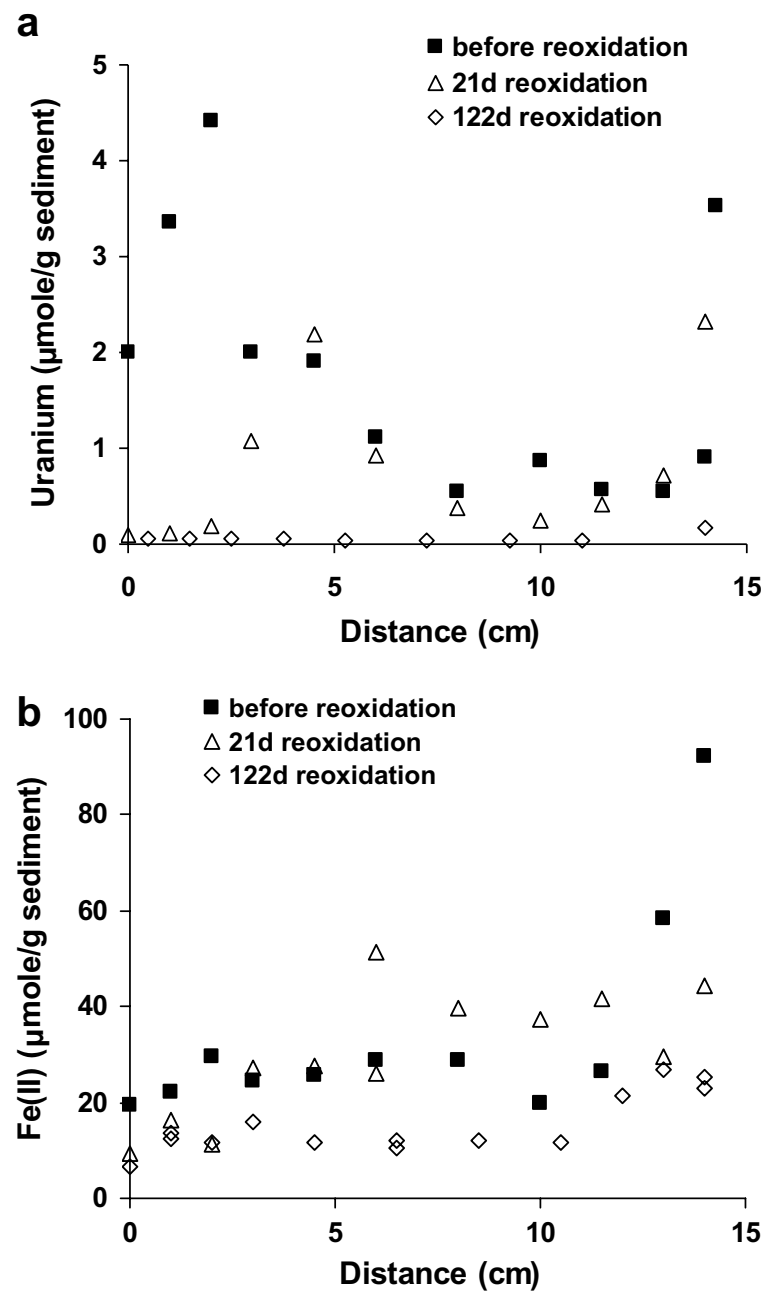

Fig. 9. Solid phase (a) uranium and (b) Fe(II) concentrations along the length of column before and after reoxidation. 9b). The decrease could have been due to the oxidation of solid phase $\mathrm{Fe}(\mathrm{II})$, either as $\mathrm{Fe}(\mathrm{II})$-silicates (e.g., Komlos et al., 2007) or other $\mathrm{Fe}(\mathrm{II})$ species. The fast and complete remobilization of uranium indicates that any $\mathrm{Fe}$ (III) formed from the oxidation of biogenic $\mathrm{Fe}(\mathrm{II})$ did not provide significant surface sites for U(VI) sorption/immobilization as was previously shown due to the oxidation of synthetic Fe(II) (Zhong et al., 2005).

Reoxidation resulted in a decrease in the estimated total cells in the column with a net loss of $7.5 \times 10^{10}$ cells within the first 21 days of reoxidation (Table 4). This net loss was due to a decrease in the methanogen population $\left(8.5 \times 10^{10}\right.$ cell decrease $)$ with the Bacteria domain increasing by $1.5 \times 10^{10}$ cells (including an increase of $1.3 \times 10^{7}$ delta-proteobacteria and $2.7 \times 10^{6}$ Geobacter cells) (Table 4). There was little change in the bacterial community composition after 21 days of reoxidation, as measured using PLFA analysis (Fig. 10a and b). This, combined with no loss in the delta-proteobacteria cell numbers (Table 4), shows that a short-term disruption in biostimulation accompanied by oxygen addition did not decimate the community structure responsible for metal (i.e., uranium) bioreduction although it did affect the methanogen population. However, there was a shift in the bacterial community structure after 122 days of reoxidation, particularly at the beginning of the column, resulting in a community composition that is more uniform throughout the column than compared to before reoxidation commenced (Fig. 10a and c).

Although oxygen was supplied to the influent media throughout the reoxidation phase, no oxygen was detected at the effluent throughout the duration of this phase. Ammonia oxidation in the column was measured from the stoichiometric production of nitrate at the effluent (Fig. 8b) starting at about day 24 of the reoxidation phase. Ammonia (0.14 mM) was supplied to the column as part of the influent media and nitrite was not detected during the reoxidation. The steady-state amount of nitrate produced from ammonia oxidation in the column (after day 75 , Fig. 8b) would consume all of the influent oxygen, explaining why oxygen did not reach the effluent. Before this time, however, other reduced species were also responsible for oxygen consumption. The theoretical amount of oxygen consumed based on reduced species oxidized between day 0 and day 21 of reoxidation (when one of the columns was destructively sampled) is shown in Table 5. The mass of U(IV), sulfide, and ammonia oxidized was based on the amount of effluent U(VI), sulfate, and nitrate (respectively) measured above influent concentrations up to day 21 of reoxidation. The mass of $\mathrm{Fe}(\mathrm{II})$ and cells oxidized

Table 4

Total biomass, methanogen, bacteria, delta-proteobacteria and Geobacter concentrations throughout the column just before reoxidation and after 21 day of reoxidation

\begin{tabular}{llllll}
\hline & Total cells & Methanogens cells & Bacteria cells & Delta-proteobacteria cells & Geobacter cells \\
\hline$T=0$ reoxidation & $1.4 \times 10^{11}$ & $8.6 \times 10^{10}$ & $5.3 \times 10^{10}$ & $7.0 \times 10^{6}$ & $1.5 \times 10^{6}$ \\
$T=21$ day reoxidation & $6.5 \times 10^{10}$ & $1.1 \times 10^{9}$ & $6.8 \times 10^{10}$ & $2.0 \times 10^{7}$ & $4.3 \times 10^{6}$ \\
\hline
\end{tabular}

Total cells were estimated by taking the sum of the bacteria and methanogen populations and calculated using the same procedure described during the biostimulation discussion. 
a
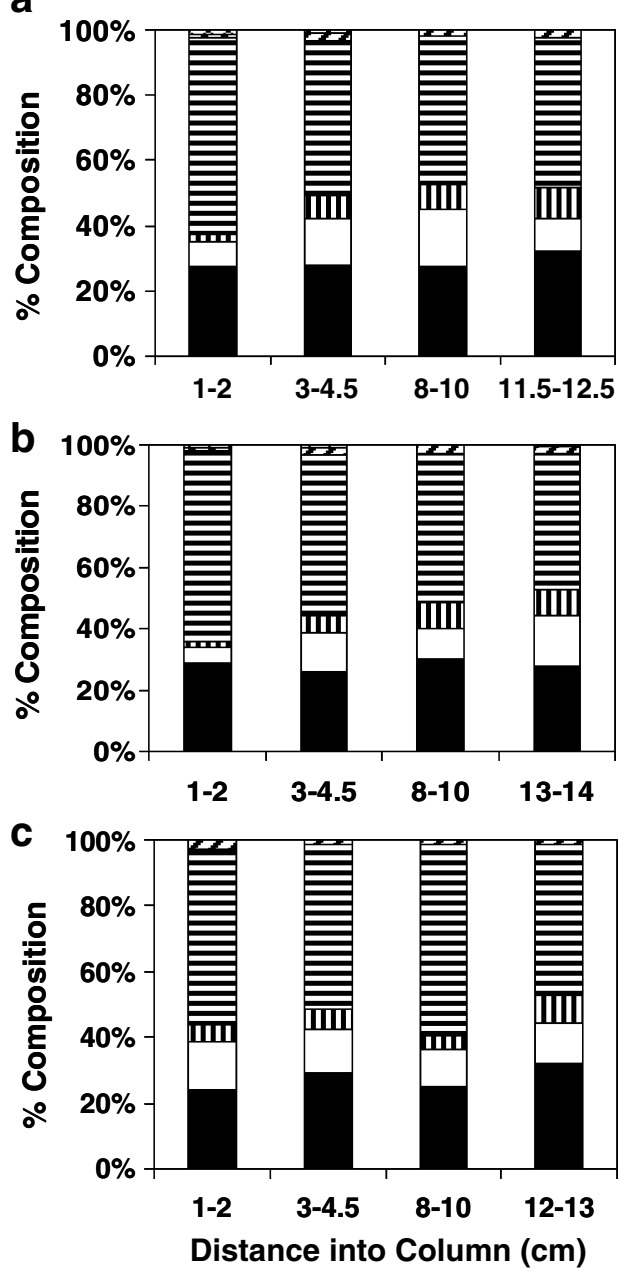

\section{normal saturates \\ $\square$ terminally branched saturates \\ W mid-chain branched saturates $\boxminus$ monounsaturates \\ $\square$ branched monounsaturates $\square$ polyunsaturates}

Fig. 10. Changes in microbial composition as measured by PLFA distribution (a) just before reoxidation, (b) 21 day of reoxidation, and (c) 122 day reoxidation. PLFA designations are explained in Fig. 7.

was estimated from the difference in solid phase $\mathrm{Fe}(\mathrm{II})$ concentrations (Fig. 9b) and total cell numbers (Table 4), respectively, before oxidation and after 21 day reoxidation. Acetate was supplied to the column during reoxidation as part of the influent $20 \mu \mathrm{M}$ uranyl acetate solution and was assumed to be fully consumed in the column $(20 \mu \mathrm{M}$ was below the range of acetate detection). Table 5 shows that the greatest oxygen demand was from cell decay ( $43 \%)$ followed by $\mathrm{Fe}(\mathrm{II})$ oxidation $(23 \%)$ while U(IV) oxidation accounted for only $12 \%$ of the oxygen demand. Even though the theoretical amount of oxygen consumed $(2.17 \mathrm{mmol})$ was greater than the mass of oxygen utilized in the column $(1.64 \mathrm{mmol})$, the results presented in Table 5 show that the extent of oxidation of the reduced species was of the same magnitude than that of U(IV) oxidation and explains why these reduced species were not able to act as an oxygen sink to measurably slow U(IV) oxidation.

\subsection{Implications for field-scale uranium bioremediation}

An important finding of this work is that significant bioavailable $\mathrm{Fe}(\mathrm{III})$ was present to support $\mathrm{Fe}(\mathrm{III})$ reducing conditions for $>200$ days and, based on the relatively constant $\mathrm{Fe}(\mathrm{II})$ production in the column, it appears that $\mathrm{Fe}(\mathrm{III})$ reduction would have continued for many additional months of biostimulation. This shows that biostimulation of an aquifer containing sediment similar to that used in this experiment (and in the absence of significant sulfate levels) iron reduction, and hence $\mathrm{U}(\mathrm{VI})$ reduction under iron reducing conditions, will occur for a relatively long time. In addition, even though there was an $\sim 30 \%$ decrease in $\mathrm{Fe}(\mathrm{III})$ reduction over the final 100 days of the experiment, the U(VI) reduction efficiency actually increased. Even with the increase in U(VI) reduction efficiency, electron transfer efficiency from acetate to U(VI) actually decreased with time of biostimulation due the microbial community dominance by microorganisms not typically associated with $\mathrm{Fe}(\mathrm{III}) / \mathrm{U}(\mathrm{VI})$ reduction and hence acetate consumption by non-U(VI) reducing processes.

The stability of the bioreduced U(IV) is a concern during reoxidation. Previous research has shown that products of iron/sulfate reduction can protect a fraction of the biologically produced U(IV) (Abdelouas et al., 1999b). However, under the conditions of this research, including low sulfate concentrations, $\mathrm{Fe}(\mathrm{II})$ accumulation during longterm biostimulation did not significantly protect U(IV) from reoxidation [biomass was actually a more significant sink of oxygen than $\mathrm{Fe}(\mathrm{II})]$. The fact that more U(IV) precipitated at the beginning of the column and more Fe(II) at the end is one of the reasons why $\mathrm{Fe}(\mathrm{II})$ did not protect U(IV) from oxidation. In addition, the lack of change in solid phase $\mathrm{Fe}(\mathrm{II})$ between day 104 and 203 of bioreduction (Fig. 4b) and the relatively uniform effluent Fe(II) concentration between day 104 and 203 (Fig. 3) shows that Fe(II) was constantly produced and exported from the column. Therefore, for this sediment, there was an inadequate buildup of biogenic $\mathrm{Fe}(\mathrm{II})$ able to react with dissolved oxygen (DO) to be a significant sink of DO to prevent U(IV) oxidation (Table 2). This is in contrast to our previous work (Komlos et al., 2007) using different sediment where the majority of the $\mathrm{Fe}(\mathrm{II})$ precipitated after bioreduction (little $\mathrm{Fe}(\mathrm{II})$ export) and the solid phase $\mathrm{Fe}(\mathrm{II})$ was significantly higher than in this current study, which may be due to differences in Fe-oxide properties [crystallinity, $\mathrm{Al}$ for Fe substitution, physical location (coatings, cemented particles, etc.)]. Although reoxidation resulted in significant uranium resolubilization, analysis of the microbial community before and after short-term (21 day) cessation of electron donor addition and introduction of oxygen showed little change in the iron/uranium/sulfate reducing population (as measured by Geobacter/delta-proteobacteria Q-PCR counts and PLFA bacteria community composition) even though the methanogen population was decimated $(99 \%$ reduction). This indicates that short-term stoppage of biostimulation (i.e., equipment malfunctions, etc.) may not negatively affect the microbial population responsible for uranium bioremediation once the system is brought back on-line, and that it may actually be implemented as 
Table 5

Mass balance of oxidation of reduced species to oxygen consumed after 21 days of reoxidation

\begin{tabular}{llllc}
\hline Reduced species & Stoichiometry & $\begin{array}{l}\text { Amount reoxidized } \\
(\mathrm{mmol})\end{array}$ & \multicolumn{2}{c}{ Theoretical oxygen consumed } \\
\cline { 3 - 5 } & & 0.528 & 0.264 \\
$(\mathrm{mmol})$
\end{tabular}

Mass of oxygen consumed after 21 days was $1.64 \mathrm{mmol}$.

${ }^{\text {a }}$ Using half redox reactions from Abdelouas et al. (1999a).

${ }^{\mathrm{b}}$ Using half redox reactions from Morel and Hering (1993).

${ }^{c}$ Using a cell composition of $\mathrm{C}_{5} \mathrm{H}_{7} \mathrm{O}_{2} \mathrm{~N}$.

d 1 cell $=2.8 \times 10^{-13} \mathrm{~g}$ (for Escherichia coli cell) (Madigan et al., 1996).

a method to control the bacterial population that consumes acetate and is not involved in the reduction of uranium.

\section{ACKNOWLEDGMENTS}

This research was funded by the Environmental Remediation Sciences Program (ERSP), Office of Biological and Environmental Research (OBER), US Department of Energy (DOE; Grant DEFG02-05ER63973). Additional funding was provided by the Pacific Northwest National Laboratory Project 51882. Mössbauer and XRD analyses were performed within the W.R. Wiley Environmental Molecular Sciences Laboratory (EMSL), a national user facility sponsored by the US DOE-OBER and located at Pacific Northwest National Laboratory (PNNL). PNNL is operated for the DOE by Battelle. The authors would like to thank Dr. Deb P. Jaisi, currently with Yale University, for performing the total Fe analysis, Paul Gassman for XRD and chemical extractions, and David Hedrick for his valuable comments on the microbiological analysis. The G. metallireducens strain used was provided by Derek Lovley (U. of Mass., Amherst).

\section{REFERENCES}

Abdelouas A., Lu Y., Lutze W. and Nuttall H. E. (1999a) Uranium contamination in the subsurface: characterization and remediation. In Uranium: Mineralolgy, Mineralogy, Geochemistry, and the Environment, vol. 38 (eds. P. C. Burns and R. Finch). The Mineralogical Society of America, p. 450.

Abdelouas A., Lu Y. M., Lutze W. and Nuttall H. E. (1998) Reduction of $\mathrm{U}(\mathrm{VI})$ to $\mathrm{U}(\mathrm{IV})$ by indigenous bacteria in contaminated ground water. J. Contam. Hydrol. 35(1-3), 217233.

Abdelouas A., Lutze W. and Nuttall H. E. (1999b) Oxidative dissolution of uraninite precipitated on Navajo sandstone. $J$. Contam. Hydrol. 36(3-4), 353-375.

Anderson R. T., Rooney-Varga J. N., Gaw C. V. and Lovley D. R. (1998) Anaerobic benzene oxidation in the $\mathrm{Fe}(\mathrm{III})$ reduction zone of petroleum contaminated aquifers. Environ. Sci. Technol. 32(9), 1222-1229.

Anderson R. T., Vrionis H. A., Ortiz-Bernad I., Resch C. T., Long P. E., Dayvault R., Karp K., Marutzky S., Metzler D. R., Peacock A., White D. C., Lowe M. and Lovley D. R. (2003) Stimulating the in situ activity of Geobacter species to remove uranium from the groundwater of a uranium-contaminated aquifer. Appl. Environ. Microbiol. 69(10), 5884-5891.

Brown D. G., Komlos J. and Jaffé P. R. (2005) Simultaneous utilization of acetate and hydrogen by Geobacter sulfurreducens and implications for use of hydrogen as an indicator of redox conditions. Environ. Sci. Technol. 39, 3069-3076.

Bligh E. G. and Dyer W. J. (1959) A rapid method of total lipid extraction and purification. Can. J. Biochem. Physiol. 37(8), 911917.

Chang Y. J., Long P. E., Geyer R., Peacock A. D., Resch C. T., Sublette K., Pfiffner S., Smithgall A., Anderson R. T., Vrionis H. A., Stephen J. R., Dayvault R., Ortiz-Bernad I., Lovley D. R. and White D. C. (2005) Microbial incorporation of C-13labeled acetate at the field scale: detection of microbes responsible for reduction of $\mathrm{U}(\mathrm{VI})$. Environ. Sci. Technol. 39(23), 9039-9048.

Chao T. T. and Zhou L. (1983) Extractable techniques for selective dissolution of amorphous $\mathrm{Fe}$ oxides from soils and sediments. Soil Sci. Soc. Am. J. 47(2), 225-232.

Ditoro D. M., Mahony J. D., Hansen D. J., Scott K. J., Hicks M. B., Mayr S. M. and Redmond M. S. (1990) Toxicity of cadmium in sediments - the role of acid volatile sulfide. Environ. Toxicol. Chem. 9(12), 1487-1502.

Finneran K. T., Anderson R. T., Nevin K. P. and Lovley D. R. (2002) Potential for bioremediation of uranium-contaminated aquifers with microbial U(VI) reduction. Soil Sed. Contam. 11(3), 339-357.

Fredrickson J. K., Zachara J. M., Kennedy D. W., Duff M. C., Gorby Y. A., Li S. M. W. and Krupka K. M. (2000) Reduction of U(VI) in goethite (alpha-FeOOH) suspensions by a dissimilatory metal-reducing bacterium. Geochim. Cosmochim. Acta 64(18), 3085-3098.

Gu B. H., Yan H., Zhou P., Watson D. B., Park M. and Istok J. (2005) Natural humics impact uranium bioreduction and oxidation. Environ. Sci. Technol. 39(14), 5268-5275.

Guckert J. B., Antworth C. P., Nichols P. D. and White D. C. (1985) Phospholipid, ester-linked fatty-acid profiles as reproducible assays for changes in prokaryotic community structure of estuarine sediments. FEMS Microbiol. Ecol. 31(3), 147-158.

Gunstone F. D. and Herslöf B. (1992) A Lipid Glossary. Oily Press, p. 101.

Hales B. A., Edwards C., Ritchie D. A., Hall G., Pickup R. W. and Saunders J. R. (1996) Isolation and identification of methanogen-specific DNA from blanket bog peat by PCR amplification and sequence analysis. Appl. Environ. Microbiol. 62(2), 668-675. 
Harris D. E. (1999) Quantitative Chemical Analysis, fifth ed. W.H. Freeman and Company, New York.

Istok J. D., Senko J. M., Krumholz L. R., Watson D., Bogle M. A., Peacock A., Chang Y. J. and White D. C. (2004) In situ bioreduction of technetium and uranium in a nitrate-contaminated aquifer. Environ. Sci. Technol. 38(2), 468-475.

Jaisi D. P., Kukkadapu R. K., Eberl D. E. and Dong H. (2005) Control of $\mathrm{Fe}(\mathrm{III})$ site occupancy on the rate and extent of microbial reduction of $\mathrm{Fe}(\mathrm{III})$ in nontronite. Geochim. Cosmochim. Acta 69, 5429-5440.

Komlos J. and Jaffe P. R. (2004) Effect of iron bioavailability on dissolved hydrogen concentrations during microbial iron reduction. Biodegradation 15(5), 315-325.

Komlos J., Kukkadapu R. K., Zachara J. M. and Jaffe P. R. (2007) Biostimulation of iron reduction and subsequent oxidation of a sediment containing Fe-silicates and Fe-oxides: effect of redox cycling on Fe(III) bioreduction. Water Res. 41, 2996-3004.

Komlos J., Mishra B., Lanzirotti A., Myneni S. C. B. and Jaffe P. R. (2008) Real time speciation of uranium during active bioremediation and U(IV) reoxidation. J. Environ. Eng. 134, 78-86.

Kukkadapu R. K., Zachara J. M., Smith S. C., Fredrickson J. K. and Liu C. (2001) Dissimilatory bacterial reduction of Alsubstituted goethite in subsurface sediments. Geochim. Cosmochim. Acta 65, 2913-2924.

Kukkadapu R. K., Zachara J. M., Fredrickson J. K. and Kennedy D. W. (2004) Biotransformation of synthetic 2-line silicaferrihydrite coprecipitates by a dissimilatory $\mathrm{Fe}(\mathrm{III})$-reducing bacterium: formation of carbonate green rust in the presence of phosphate. Geochim. Cosmochim. Acta 68, 2799-2814.

Kukkadapu R. K., Zachara J. M., Fredrickson J. K., McKinley J. P., Kennedy D. W., Smith S. C. and Dong H. L. (2006) Reductive biotransformation of $\mathrm{Fe}$ in shale-limestone saprolite containing $\mathrm{Fe}(\mathrm{III})$ oxides and $\mathrm{Fe}(\mathrm{II}) / \mathrm{Fe}(\mathrm{III})$ phyllosilicates. Geochim. Cosmochim. Acta 70(14), 3662-3676.

Lack J. G., Chaudhuri S. K., Kelly S. D., Kemner K. M., O'Connor S. M. and Coates J. D. (2002) Immobilization of radionuclides and heavy metals through anaerobic bio-oxidation of $\mathrm{Fe}(\mathrm{II})$. Appl. Environ. Microbiol. 68(6), 2704-2710.

Langmuir D. (1978) Uranium solution-mineral equilibria at lowtemperatures with applications to sedimentary ore-deposits. Geochim. Cosmochim. Acta 42(6), 547-569.

Lovley D. R. and Coates J. D. (1997) Bioremediation of metal contamination. Curr. Opin. Biotechnol. 8(3), 285-289.

Lovely D. R. and Phillips E. J. P. (1986) Availability of ferric Fe for microbial reduction in bottom sediments of the freshwater tidal Potomac River. Appl. Environ. Microbiol. 52, 751-757.

Lovley D. R. and Phillips E. J. P. (1987) Rapid assay for microbially reducible ferric iron in aquatic sediments. Appl. Environ. Microbiol. 53(7), 1536-1540.

Lovley D. R. and Phillips E. J. P. (1988) Novel mode of microbial energy-metabolism - organic-carbon oxidation coupled to dissimilatory reduction of iron or manganese. Appl. Environ. Microbiol. 54(6), 1472-1480.

Lovley D. R. and Phillips E. J. P. (1992a) Bioremediation of uranium contamination with enzymatic uranium reduction. Environ. Sci. Technol. 26(11), 2228-2234.
Lovley D. R. and Phillips E. J. P. (1992b) Reduction of uranium by Desulfovibrio-Desulfuricans. Appl. Environ. Microbiol. 58(3), 850-856.

Madigan M. T., Martinko J. M. and Parker J. (1996) Brock Biology of Microorganisms. Prentice-Hall, Inc.

Moon H. S., Komlos J. and Jaffe P. R. (2007) Uranium reoxidation in previously bioreduced sediment by dissolved oxygen and nitrate. Environ. Sci. Technol. 41(13), 4587-4592.

Morel M. M. and Hering J. G. (1993) Principles and Applications of Aquatic Chemistry. John Wiley \& Sons, Inc.

Murad E. and Cashion J. (2004) Mossbauer Spectroscopy of Environmental Materials and their Industrial Utilization. Kluwer Academic Publishers, NY/London/Boston/Dordrecht.

Schwertmann U. (1959) Die fraktionierte Extraktion der freien Eisenoxyde in Böden, ihre mineralogischen Formen und ihre Entstehyngwweisen (in German). Z. Pflanz. Dünger Bodenk. 84, 194-204.

Senko J. M., Istok J. D., Suflita J. M. and Krumholz L. R. (2002) In-situ evidence for uranium immobilization and remobilization. Environ. Sci. Technol. 36(7), 1491-1496.

Stults J. R., Snoeyenbos-West O., Methe B., Lovley D. R. and Chandler D. P. (2001) Application of the $5^{\prime}$ fluorogenic exonuclease assay (TaqMan) for quantitative ribosomal DNA and rRNA analysis in sediments. Appl. Environ. Microbiol. 67(6), 2781-2789.

Suzuki M. T., Taylor L. T. and DeLong E. F. (2000) Quantitative analysis of small-subunit rRNA genes in mixed microbial populations via $5^{\prime}$-nuclease assays. Appl. Environ. Microbiol. 66(11), 4605-4614.

Taylor S. W. and Jaffe P. R. (1991) Enhanced in situ biodegradation and aquifer permeability reduction. J. Environ. Eng.-ASCE 117(1), 25-46.

White D. C., Bobbie R. J., Heron J. S., King J. D. and Morrison S. J. (1979) Biochemical measurements of microbial mass and activity from environmental samples. In Native Aquatic Bacteria: Enumeration, Activity, and Ecology (eds. J. W. Costerton and R. R. Colwell). ASTM STP 695. American Society for Testing and Materials, pp. 69-81.

White D. C. and Ringelberg D. B. (1998) Signature lipid biomarker analysis. In Techniques in Microbial Ecology (eds. R. S. Burlage, R. Atlas, D. Stahl, G. Geesey and G. Sayler). Oxford University Press, pp. 255-272.

White D. C., Stair J. O. and Ringelberg D. B. (1996) Quantitative comparisons of in situ microbial biodiversity by signature biomarker analysis. J. Ind. Microbiol. 17(3-4), 185-196.

Zachara J. M., Fredrickson J. K., Li S. M., Kennedy D. W., Smith S. C. and Gassman P. L. (1998) Bacterial reduction of crystalline $\mathrm{Fe}^{3+}$ oxides in single phase suspensions and subsurface materials. Am. Mineral. 83(11-12), 1426-1443.

Zhong L. R., Liu C. X., Zachara J. M., Kennedy D. W., Szecsody J. E. and Wood B. (2005) Oxidative remobilization of biogenic uranium(IV) precipitates: effects of iron(II) and pH. J. Environ. Qual. 34(5), 1763-1771.

Associate editor: Lesley A. Warren 